Jurnal Tarbawi| Volume 1|No 1| ISSN 2527-4082| 21

\title{
PENGARUH KEDISIPLINAN GURU TERHADAP PRESTASI BELAJAR
}

\author{
Ahmad Nashir ${ }^{1}$ \\ Pendidikan Agama Islam Fakultas Agama Islam| Unismuh Makassar
}

\begin{abstract}
ABSTRAK
Penelitian ini merupakan penelitian statistik deskriptif kuantitatif, untuk mengetahui pengaruh variabel kedidiplinan guru terhadap prestasi belajar siswa SMP Unismuh Makassar. Populasi penelitian ini adalah seluruh siswa SMP Unismuh Makassar yang berjumlah 153 orang. Sampel pada penelitian ini diambil sebanyak $30 \%$ dari populasi yaitu sebanyak 50 orang. Teknik pengumpulan data menggunakan teknik observasi, pemberian angket, wawancara, dan dokumentasi. Data yang dikumpulkan tersebut dianalisis dengan analisis regresi untuk mengetahui pengaruh antarvariabel, yaitu pengaruh variabel kedisiplinan guru terhadap preatsi belajar siswa. Hasil penelitian menunjukkan bahwa pelaksanaan kedisiplinan guru di SMP Unismuh Makassar berdasarkan data, diperoleh nilai $R$ sebesar 0, 714 yang menunjukkan pengaruh yang sangat besar antar variabel. Selain itu diperoleh $R$ square sebesar 0,51 yang menunjukkan bahwa kedisiplinan guru mempengaruhi prestasi belajar siswa di SMP Unismuh Makassar 51, \% dan sisa yaitu 49\% yang dipengaruhi variabel lain.
\end{abstract}

Kata Kunci : Kedisiplinan, Prestasi belajar

\begin{abstract}
This research is a quantitative descriptive statistics, to determine the effect of variable kedidiplinan teachers on student achievement SMP Unismuh Makassar. The study population was all students of SMP Unismuh Makassar totaling 153 people. Is Sample in this research taken as much as $30 \%$ of the population of many as 50 people. The collection techniques using observation, giving inquiry, interviews, and documentation. The collection were analyzed using regression analysis to determine the effect among variables, namely the effect of variable preatsi discipline of teachers to student learning. The results showed that the implementation of the discipline of teachers in junior hight school Unismuh Makassar based on the inquiry, obtained by the $R$ number of 0,714 which shows the enormous influence among variables. Additionally obtained $R$-square of 0.51 indicating that the discipline of teachers affect student achievement in junior hight school Unismuh Makassar 51,\% and the remainder of which $49 \%$ are influenced by other variables.
\end{abstract}

Keywords: Discipline, learning achievement 


\section{PENDAHULUAN}

Perkembangan ilmu pengetahuan dan teknologi saat ini mempercepat modernisasi segala bidang sehingga menimbulkan persaingan yang ketat antar bangsa. Berbagai perkembangan semakin kuat sejalan dengan tuntutan reformasi dan globalisasi. Untuk menghadapi keadaan tersebut diperlukan sumber daya manusia (SDM) yang berkualitas tinggi. Pembangunan sumber daya manusia yang berkualitas tinggi adalah untuk menciptakan dan mengembangkan ilmu pengetahuan dan teknologi sebagai sarana mewujudkan masyarakat yang mampu bersaing untuk menghadapi tantangan di era globalisasi. Peningkatan sumber daya manusia dapat dilakukan melalui jalur pendidikan, baik pendidikan formal di sekolah, non formal di lingkungan masyarakat dan informal dalam lingkungan keluarga.

$$
\text { Salah satu amanat Undang- }
$$

Undang Dasar Negara Republik Indonesia Tahun 1945 tersebut kemudian diatur lebih lanjut dalam Undang-Undang Nomor 20 Tahun 2003 tentang Sistem Pendidikan Nasional, yang memiliki visi terwujudnya sistem pendidikan sebagai pranata sosial yang kuat dan berwibawa untuk memberdayakan semua warga negara Indonesia berkembang menjadi manusia yang berkualitas sehingga mampu dan proaktif menjawab tantangan zaman yang selalu berubah.

Kualitas manusia yang dibutuhkan oleh bangsa Indonesia pada masa yang akan datang adalah yang mampu menghadapi persaingan yang semakin ketat dengan bangsa lain di dunia. Kualitas manusia Indonesia tersebut dihasilkan melalui penyelenggaraan pendidikan yang bermutu. Oleh karena itu, guru mempunyai fungsi, peran, dan kedudukan yang sangat strategis. Pasal 39 ayat (2) Undang-Undang Nomor 20 Tahun 2003 tentang Sistem Pendidikan Nasional menyatakan bahwa pendidik merupakan tenaga profesional. Kedudukan guru sebagai tenaga profesional mempunyai visi terwujudnya penyelenggaraan pembelajaran sesuai dengan prinsip-prinsip profesional untuk memenuhi hak yang sama bagi setiap warga negara dalam memperoleh pendidikan yang bermutu.

Seorang guru hendaknya tidak pernah tamak dan bathil dalam menjalankan tugasnya sehari-hari, seorang guru semata-mata hanya mengharapkan ganjaran dari Allah swt. Sebagai mana dinyatakan dalam dalam firman Allah QS. Huud(11): 51:

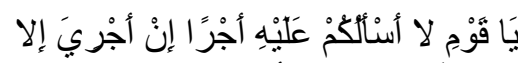

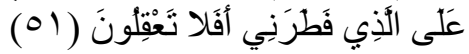

Terjemahnya:

"Hai kaumku, aku tidak meminta upah kepadamu bagi seruanku ini. Upahku tidak lain hanyalah dari Allah yang telah menciptakanku. Maka tidakkah kamu memikirkan (nya)?" (Departemen Agama RI: 227)

Seorang guru harus meyakini bahwa Islam sebagai konsep Ilahi. Dimana dia hidup dengan konsep itu, dan mampu mengamalkannya. Karena sumber dari segala sumber ilmu pengetahuan yang dimiliki oleh guru itu adalah Allah. Sehingga wajar, jika seorang guru mengorbankan semua yang dimilikinya, waktu, tenaga, harta benda dan pikiran, semata-mata karena Allah.

Kedisiplinan guru menjadi sangat berarti bagi keberhasilan seorang guru dalam mengajar dan kemajuan 
sekolah serta meningkatkan prestasi belajar siswa. Di sekolah yang tertib akan selalu menciptakan proses pembelajaran yang menyenangkan. Sebaliknya, pada sekolah yang tidak tertib kondisinya akan jauh berbeda dengan sekolah yang menerapkan disiplin yang tinggi. Ajaran Islam sangat menganjurkan pemeluknya untuk menerapkan disiplin dalam berbagai aspek kehidupan, baik ibadah, belajar dan kegiatan lainnya sebagaimana dalam menjalankan fardhu'ain di dalam Islam yang berupa sholat lima waktu, puasa Ramadhan dan lain-lain semua itu sungguh merupakan suatu latihan atau yang sangat berarti untuk disiplin diri sendiri (self discipline).Hadis Rasulullah saw. Bersabda:

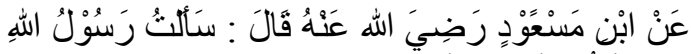

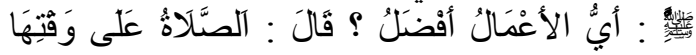
(متفق عليه)

Terjemahannya: dari Ibnu Mas'ud meridhai Allah daripadanya berkata: saya telah bertanya kepada Rasulullah Saw : pekerjaan apa yang paling Afdhal: Rasulullah saw. bersabda yaitu sholat tepat pada waktunya. (HR.Muttafaq Alaih) Abi Zakariya (676: 210)

Shalat harus dilaksanakan tepat pada waktunya sebagaimana anjuran tercantum dalam hadisnya. Dalam melaksanakan shalatpun mengandung unsur-unsur kedisiplinan, karena dalam melaksanakan shalat ada aturan, syaratsyarat dan rukun-rukun yang harus terpenuhi demi kesempurnaan shalat tersebut. Sepintas bila mendengar kata disiplin maka yang selalu terbayang usaha untuk menyekat, mengawal dan menahan. Padahal tidak demikian, sebab disiplin bermakna melatih, mendidik dan mengatur atau hidup teratur. Artinya kata disiplin itu tidak terkandung makna sekatan, tetapi suatu latihan. Untuk itulah kedisiplinan sangat diperlukan dalam usaha meningkatkan suatu kehidupan yang teratur dan meningkatkan prestasi dalam belajar karena sifatnya yang mengatur dan mendidik. Dari kebanyakan orang-orang sukses rasanya tidak ada di antara mereka yang tidak berdisiplin, kedisiplinan yang tertanam dalam setiap kegiatan membawa kesuksesan.

Sikap kedisiplinan inilah yang coba ditanamkan oleh para guru SMP Unismuh Makassar. SMP Unismuh Makassar adalah salah satu amal usaha Muhammadiyah dalam bidang pendidikan khususnya pendidikan agama Islam, akan tetapi dalam pembinaan siswa di sekolah ini yang berusaha mengintegrasikan ilmu agama dan ilmu umum dalam nuansa religius dan sebagai gerakan tajdid sejalan dengan tujuan persyarikatan Muhammadiyah.

\section{METODE PENELITIAN}

Lokasi penelitian berada di wilayah Kota Makassar Provinsi Sulawesi Selatan, dengan objek penelitian pada SMP Unismuh Makassar. Jenis penelitian yang digunakan adalah penelitian deskriptif kuantitatif. Penelitian ini berdasarkan atas paradigma positivisme yang berpandangan bahwa peneliti dapat dengan sengaja mengadakan perubahan terhadap dunia sekitar dengan melakukan berbagai eksperimen. Para penganut positivisme percaya bahwa manusia dapat menemukan aturanaturan, hukum-hukum, dan prinsipprinsip umum tentang dunia kenyataan baik dalam ilmu-ilmu alam maupun 
dalam ilmu-ilmu sosial termasuk pendidikan.

Di samping itu penelitian kuantitatif dapat dijelaskan ciri-cirinya ditinjau dari operasionalisasinya, yaitu:(1) desain penelitian kuantitatif bersifat spesifik, jelas, rinci, hipotesis dirumuskan dengan tegas dan ditentukan secara mantap sejak awal untuk dijadikan pegangan bagi setiap langkah penelitian yang dilakukan, (2) tujuan penelitian kuantitatif adalah untuk menunjukkan hubungan antar variabel, menguji teori dan mencari generalisasi yang mempunyai nilai prediktif, (3) instrumen penelitian menggunakan tes, angket, wawancara, dengan alat berupa kalkulator, komputer, dan sebagainya, (4) data penelitian bersifat kuantitatif yang diperoleh dari hasil pengukuran berdasarkan variabel yang dioperasionalkan dengan menggunakan instrumen, (5) sampelnya besar, representatif, dan diusahakan sedapat mungkin diambil secara random, (6) analisis data dilakukan pada tahap akhir setelah pengumpulan data selesai, bersifat deduktif dan menggunakan statistik, dan (7) hubungan antara peneliti dengan responden berjarak, sering tanpa kontak langsung.

Variabel yang dilibatkan dalam penelitian ini adalah kedisiplinan guru dan prestasi belajar siswa. Kedisiplinan guru sebagai peubah atau variabel bebas (independent variable), diberi simbol $\mathrm{X}$, sedangkan prestasi belajar siswa merupakan variabel respons (dependent variable) dan diberi simbol Y.

Pola hubungan antara variabel bebas dengan variabel terikat dapat dilukiskan dalam gambar di bawah ini:

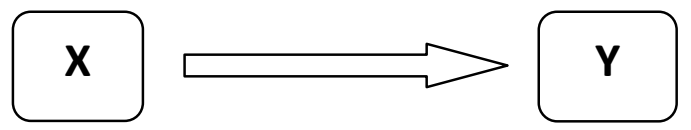

Gambar 2. Skema Hubungan Variabel
Keterangan:

$$
\begin{array}{ll}
\mathrm{X} & : \text { Kedisiplinan Guru } \\
\mathrm{Y} & : \text { Prestasi Belajar Siswa }
\end{array}
$$

\section{HASIL DAN PEMBAHASAN}

SMP Unismuh Makassar adalah salah satu lembaga pendidikan tingkat menengah di bawah bimbingan Badan Pengurus Harian (BPH) Universitas Muhammadiyah Makassar. Meskipun sekolah ini merupakan sekolah swasta, namun diharapkan sekolah ini dapat mencetus generasi penerus bangsa yang beriman, intelek, kreatif, inovatif, dan berakhlak mulia sehingga mampu berguna bagi agama, bangsa dan negara Republik Indonesia. Hal ini sesuai dengan tujuan pendidikan nasional dan untuk mencapai tujuan pendidikan nasional pada umumnya, serta tujuan pendidikan sekolah pada khusunya.

Melalui Kurikulum pembelajaran terpadu di sekolah ini, siswa dapat mengintegrasikan antara pendidikan agama dan pendidikan umum, serta dapat melaksanakan program pendidikannya sesuai dengan karakteristik potensi dan kebutuhan peserta didik, sehingga dalam pengembangannya perlu melibatkan seluruh stake holder sekolah dengan koordinasi kepada pemangku kepentingan lingkungan sekitar sekolah.

\section{Gambaran Kedisiplinan Guru di SMP Unismuh Makassar}

Kedisiplinan guru diukur dari 6 indikator utama, yaitu akseptansi, energi kemauan, bekerja keras, menghargai waktu, mengembangkan produktivitas personal, dan persistensi. Dalam hal ini, pelaksanaan kedisiplinan guru, telah tertuang dalam bentuk angket yang diisi sesuai dengan tanggapan siswa sebagai responden. 
Akseptansi

Akseptansi diukur menggunakan kuesioner dengan 3 item pertanyaan meliputi penyetoran hasil ujian tepat waktu, pemeriksaan PR dan pengembaliannya tepat waktu kepada siswa, penjelasan tujuan pembelajaran kepada siswa. Hasil analisis secara deskriptif berupa penilaian siswa terhadap akseptansi diri ditunjukkan melalui tabel 1 berikut.

\section{Tabel 1}

Penyetoran Hasil Ujian Tepat Waktu

\begin{tabular}{|c|c|c|c|}
\hline $\begin{array}{c}\text { Klasifi } \\
\text { kasi }\end{array}$ & $\begin{array}{c}\text { Frekuen } \\
\text { si }\end{array}$ & $\begin{array}{c}\text { Perse } \\
\text { ntase }\end{array}$ & $\begin{array}{c}\text { Persen } \\
\text { kumulatif }\end{array}$ \\
\hline Selalu & 24 & 48 & 48 \\
Sering & 24 & 48 & 96 \\
Kadang & 2 & 4 & 100 \\
- & - & - & 100 \\
Kadang & & & \\
Tidak & & & \\
Pernah & \multicolumn{3}{|c|}{ 100 } \\
\hline Jumlah & 50 & \multicolumn{3}{|c|}{ Berdasarkan hasil olah data } \\
\hline \multicolumn{4}{|c|}{}
\end{tabular}

penyebaran angket terhadap 50 responden mengenai penyetoran hasil ujian tepat waktu dipandang bahwa guru selalu menyetor hasil ujian tepat waktu sebanyak 24 responden atau 48\%, 24 responden atau 48 mengatakan sering, dan tidak terdapat responden yang mengatakan kadang-kadang dan tidak pernah. Hal tersebut mengisyaratkan bahwa guru menjalankan fungsi manajemen yang baik dalam hal penyetoran hasil ujian sehingga siswa dapat melihat hasil belajarnya dan termotivasi memperbaiki hasil belajarnya sehingga prestasi belajarnya meningkat.

\section{Bekerja keras}

Indikator bekerja keras diukur menggunakan kuesioner dengan 2 item pertanyaan meliputi pemberian motivasi pada saat mengajar, menciptakan suasana mengajar yang santai dan menyenangkan. Hasil analisis secara deskriptif berupa penilaian siswa terhadap bekerja keras ditunjukkan melalui tabel berikut.

Tabel 2

Pemberian Motivasi pada saat Mengajar

\begin{tabular}{|l|c|c|c|}
\hline $\begin{array}{c}\text { Klasifika } \\
\text { si }\end{array}$ & $\begin{array}{c}\text { Frek } \\
\text { uensi }\end{array}$ & $\begin{array}{c}\text { Persen } \\
\text { tase }\end{array}$ & $\begin{array}{c}\text { Persen } \\
\text { Kumula } \\
\text { tatif }\end{array}$ \\
\hline Selalu & 32 & 64 & 64 \\
\hline Sering & 17 & 34 & 98 \\
\hline $\begin{array}{l}\text { Kadang- } \\
\text { kadang }\end{array}$ & 1 & 2 & 100 \\
\hline $\begin{array}{l}\text { Tidak } \\
\text { Pernah }\end{array}$ & - & - & 100 \\
\hline Jumlah & 50 & 100 & \\
\hline \multicolumn{2}{|c|}{ Berdasarkan tabel tersebut di }
\end{tabular}
atas, dapat dijelaskan bahwa responden penelitian memberikan penilaian terhadap guru yang memberikan motivasi pada saat mengajar sebanyak 32 orang atau $64 \%$ memberikan penilaian mengatakan selalu, 17 orang atau 34\% mengatakan sering, 1 orang atau 2\% mengatakan kadang-kadang, dan tidak ada yang memberikan penilaian pada kategori tidak pernah.

Tabel 3

Guru menciptakan suasana mengajar yang santai dan menyenangkan

\begin{tabular}{|l|c|c|c|}
\hline Klasifikasi & $\begin{array}{c}\text { Freku } \\
\text { ensi }\end{array}$ & $\begin{array}{c}\text { Perse } \\
\text { ntase }\end{array}$ & $\begin{array}{c}\text { Persen } \\
\text { Kumula } \\
\text { tatif }\end{array}$ \\
\hline Selalu & 17 & 34 & 34 \\
\hline Sering & 24 & 48 & 82 \\
\hline $\begin{array}{l}\text { Kadang- } \\
\text { kadang }\end{array}$ & 9 & 18 & 100 \\
\hline $\begin{array}{l}\text { Tidak } \\
\text { Pernah }\end{array}$ & - & - & 100 \\
\hline Jumlah & 50 & 100 & \\
\hline
\end{tabular}


Berdasarkan tabel tersebut di atas, dapat dijelaskan bahwa responden penelitian memberikan penilaian terhadap guru yang menciptakan suasana mengajar yang santai dan menyenangkan sebanyak 17 orang atau $34 \%$ mengatakan selalu, 24 orang atau $48 \%$ mengatakan sering, 9 orang atau $18 \%$ pada kategori kadang-kadang, dan tidak ada yang memberikan penilaian pada kategori tidak pernah.

\section{Menghargai waktu}

Menghargai waktu diukur menggunakan kuesioner dengan 3 item pertanyaan meliputi kehadiran guru di sekolah tepat waktu, mengajar di kelas tepat waktu, dan mengajar sesuai dengan jam mengajar. Hasil analisis secara deskriptif berupa penilaian siswa terhadap menghargai waktu ditunjukkan melalui tabel berikut

\section{Tabel 4}

\begin{tabular}{|c|c|c|c|}
\hline \multicolumn{4}{|c|}{ Kehadiran Guru di Sekolah Tepat } \\
\hline $\begin{array}{l}\text { Klasifik } \\
\text { asi }\end{array}$ & $\begin{array}{c}\text { Fre } \\
\text { kue } \\
\text { nsi }\end{array}$ & $\begin{array}{l}\text { Prese } \\
\text { ntase }\end{array}$ & $\begin{array}{c}\text { Persen } \\
\text { Kumula } \\
\text { tif }\end{array}$ \\
\hline Selalu & 16 & 32 & 32 \\
\hline Sering & 29 & 58 & 80 \\
\hline $\begin{array}{l}\text { Kadang- } \\
\text { kadang }\end{array}$ & 5 & 10 & 100 \\
\hline $\begin{array}{l}\text { Tidak } \\
\text { Pernah }\end{array}$ & - & - & \\
\hline Jumlah & 50 & 100 & \\
\hline
\end{tabular}

Berdasarkan tabel tersebut di atas, dapat dijelaskan bahwa secara responden penelitian memberikan penilaian terhadap kehadiran guru di sekolah tepat waktu sebanyak 16 orang atau 32\% memberikan penilaian selalu, 29 orang atau $58 \%$ mengatakan sering, 5 orang atau $10 \%$ pada mengatakan kadang-kadang, dan tidak ada yang memberikan penilaian pada kategori tidak pernah.

\section{Deskripsi Prestasi Belajar Siswa SMP Unismuh Makassar}

Berdasarkan hasil analisis deskriptif hasil belajar Pendidikan siswa SMP Unismuh Makassar, maka kita dapat mengetahui beberapa informasi meliputi nilai rata-rata, nilai tengah, modus standar deviasi, nilai maksimum, dan nilai minimum siswa. Hasil analisis data tersebut diperlihatkan secara jelas pada tabel berikut:

Tabel 24. Hasil Analisis Deskriptif Prestasi Belajar Siswa SMP Unismuh Makassar

Tabel di atas memperlihatkan nilai hasil analisis statistik deskriptif penelitian. Besarnya nilai rata-rata (mean) adalah 81,48 , nilai modus adalah 85 , nilai tengah (median) adalah 81 . Hasil analisis deskriptif tersebut menunjukkan bahwa nilai rata-rata siswa SMP Unismuh Makassar lebih besar dibanding nilai tengah dan berada pada kategori tinggi. Nilai terendah siswa 74 dan tertinggi adalah 90. Adapun nilai standar deviasi sebesar 3,477. Sehingga informasi lain juga dapat diperoleh, seperti rentang nilai hasil belajar adalah 16 karena rentang nilainya berada pada poin 74 sampai 90 .

Tabel 5

Skor Prestasi Belajar Siswa SMP Unismuh Makssar

\begin{tabular}{|l|l|l|l|}
\hline No & $\begin{array}{c}\text { Rentang } \\
\text { Nilai }\end{array}$ & $\begin{array}{l}\text { Frekue } \\
\text { nsi }\end{array}$ & $\begin{array}{c}\text { Persent } \\
\text { ase }\end{array}$ \\
\hline 1 & $74-77$ & 6 & 12 \\
\hline 2 & $78-81$ & 20 & 40 \\
\hline 3 & $82-85$ & 19 & 38 \\
\hline 4 & $86-89$ & 4 & 8 \\
\hline 5 & $90-93$ & 1 & 2 \\
\hline & Total & $\mathbf{5 0}$ & $\mathbf{1 0 0}$ \\
\hline
\end{tabular}


Berdasarkan tabel di atas, dapat terlihat jelas bahwa perolehan nilai prestasi belajar siswa cenderung berada pada nilai 78 - 81, yaitu sebanyak $40 \%$. Hal ini menunjukkan bahwa prestasi belajar siswa termasuk dalam kategori baik. Meskipun masih ada beberapa siswa yang memiliki nilai standar yaitu pada rentang 74 - 77 sebanyak 6 orang (12).

\section{Faktor Pendukung dan Penghambat Penerapan Kedisiplinan Guru terhadap Prestasi Belajar Siswa di SMP Unismuh Makassar}

1) Faktor Pendukung

Ada beberapa faktor pendukung kedisiplinan guru adalah:

a. Sistem/aturan sekolah yang baik, SDM yang melaksanakan aturan dengan baik, dan kontrol masyarakat;

b. Adanya ketegasan dari pimpinan sekolah yang membeikan sanksi bagi guru yang tidak disiplin;

c. Keadaan para siswa ternyata tidak semua ingin melanggar, banyak siswa yang tertib daripada yang tidak tertib;

d. Koordinasi dan kerjasama seluruh pimpinan sekolah sangat mendukung terciptanya disiplin di sekolah;

e. Fasilitas sekolah seperti internet, perpustakaan, media pembelajaran dan lain-lain juga mendukung guru untuk mengembangkan dirinya dalam meningkakan prestasi belajar siswanya;

f. Lingkungan yang Islami sehingga menciptakan suasana disiplin.

2) Faktor penghambat

Adapun faktor penghambatnya adalah: a. Jarak rumah ke sekolah cukup jauh, sehingga guru sering terlambat ke sekolah; b. Status guru yang tidak terikat dengan pihak sekolah;

b. Banyaknya pekerjaan guru sehingga tidak dapat segera menindaklanjuti seluruh tugas-tugas siswa.

c. Guru tidak sepenuhnya mengajar di sekolah tapi banyak tugas yang lain di samping di menjadi seorang guru.

d. guru kurang memahami pentingnya disipilin dan akibat melanggar disiplin.

\section{KESIMPULAN}

Berdasarkan uraian-uraian dan hasil analisis yang dikemukakan pada bab sebelumnya, dapat ditunjukkan beberapa simpulan sebagai berikut: Kedisiplinan guru di SMP Unismuh Makassar memberi pengaruh yang positif terhadap peningkatan prestasi belajar siswa, hal ini ditandai dengan perolehan prestasi belajar siswa yang cenderung berada pada nilai $78-81$, yaitu sebanyak $41 \%$. Hal ini menunjukkan bahwa prestasi belajar siswa di SMP Unismuh Makassar termasuk dalam kategori baik. Meskipun masih ada beberapa siswa yang memiliki nilai standar yaitu pada rentang $74-77$ sebanyak 6 orang (12\%). Terdapat pengaruh positif dan signifikan antara kedisiplinan guru terhadap prestasi belajar siswa. Hal ini menunjukkan bahwa semakin baik kedisiplinan guru, maka akan berdampak semakin tingginya prestasi belajar siswa di SMP Unismuh Makassar. Dalam penelitian ini, kedisiplinan guru memengaruhi prestasi belajar siswa sebesar $51 \%$, sedangkan selebihnya sebesar $49 \%$ dipengaruhi oleh faktor lain yang tidak dimasukkan dalam model penelitian ini. 
Hal demikian harus senantiasa dijaga dan perlu dilestarikan demi kemajuan sekolah, terutama di SMP Unismuh Makassar. Di antara yang menjadi penghambat kedisiplinan guru di SMP Unismuh Makassar yaitu; pertama, jarak rumah dan sekolah yang jauh sehingga terkadang guru terlambat ke sekolah, ditambah dengan volume kendaraan yang semakin meningkat sehingga dapat mengakibatkan kemacetan. Kedua, tugas guru terlalu banyak sehingga dapat mengakibatkan terbengkalainya tugas-tugas guru disekolah, misalnya tempat mengajar yang tidak fokus pada satu sekolah. Ketiga, guru tidak terikat di sekolah sehingga guru tidak mengabdi full di SMP Unismuh Makassar.

\section{DAFTAR PUSTAKA}

Abdul Mujib, Muhaimin. 1993. Pemikiran Pendidikan Islam: Kajian Filosofis dan Kerangka Dasar Operasional, Bandung: Trigenda Karya.

Arikunto, Suharsimi. 2006. Prosedur Penelitian Suatu Pendekatan Praktik, Cet. XIII; Jakarta : PT Rineka Cipta Al-qur'anul Karim dan Terjemahannya

Asmani, J Ma'mur. 2011. Tips Sukses Pendidikan dan Latihan Profesi Guru, Cet. I; Yogyakarta: Diva Press

Danim,

Sudarwan.

2011. Pengembangan Profesi Guru: dari Prajabatan, Induksi, Ke Profesional Madani, Cet. I; Jakarta: Kencana Prenada Media Group

Departemen Agama RI. 2006. Al quran dan Terjemahannya. Bandung: PT Syamil Cipta Media
Getteng, Rahman. 2011. Мепији Guru Profesional dan Ber-Etika, Cet. III; Yogyakarta: Graha Guru.

Isa, Muhammad Kamal. 1994. Manajemen Pendidikan Islam, Cet. I; Jakarta: PT Fikahati Aneska.

Meichati, Siti. 1975. Pendidikan

Sistematis. Yogyakarta: FIP IKIP

Nawawi, Hadari. t.th. Metode

Penelitian Bidang Sosial (Cet.VIII;

Yogyakarta: Gajah Mada University Press

Prijodarminto, Soegeng. 1994. Disiplin Kiat Menuju Sukses, Cet II, Jakarta: CV Pradnya Paramit

Purwanto. 2003. Psikologi

Pendidikan, Cet. XIX; Bandung: PT Remaja Rosda Karya.

Slameto, 2003. Belajar dan Faktor-Faktor yang Mempengaruhinya, Cet. IV; Jakarta: PT Rineka Cipta

Srijanto Djarot, Waspodo Eling, BA, Mulyadi. 1994. Tata Negara Sekolah Menengah Umum. Surakarta: PT Pabelan

Sudjana, Nana. 1991. Tuntunan

Penyusunan Karya Ilmiah. Bandung: Sinar Baru.

Sugiyono, 2007. Metode Penelitian Administrasi. Cet. XV; Bandung : CV Alfabeta

Sukardi, Ketut Dewa. 1983. Bimbingan dan Penyuluhan Belajar di Sekolah, Cet. I; Surabaya: Usaha Nasional.

Sutrisno, Hadi. 1975. Statistik, Jilid II, Yogyakarta: Yayasan Psikologi UGM.

Tohirin. 2006. Psikologi Pembelajaran Pendidikan Agama Islam, Jakarta: PT Rajagrafindo Persada. 